\title{
APPLICATION OF THE PRINCIPLE OF ELECTROCONDUCTIVITY AND THE USE OF EC SCANNER FOR DETERMINING THE PROPERTIES OF THE SOIL
}

\author{
Mladen Jurišić, Ivan Plaščak, Željko Barač, Domagoj Zimmer
}

Original scientific paper

Researches (2011 and 2014) about the electro conductivity of the soil and its importance in the inventorying of soils were conducted on the experimental stations of the Belje Company. Through this research the hypothesis about the importance of application of the principle of electro conductivity in the process of determining the properties of the soil through the use of ES scanners was confirmed. Regarding the application of methods according to the principle of electro conductivity of the soil, it is evident that randomized sampling method i.e. the samples were not sufficiently homogeneous and precise, whereas the predictive method of sampling was more advanced and the samples were more homogenous and presented the state on the production level better. During the research conducted through method "Z scheme", 324 GPS points were performed, while when using randomized method, in which it is not obligatory to cover the whole area, 252 GPS points were counted. This fact indicates that this method is particularly reliable when drafting a map, which is intended to be used in agricultural practice, and it is recommended for decision making regarding agricultural operations, such as fertilizing, plant protection operations, land reclamation and levelling the ground.

Keywords: agricultural operations; crop production; electrical conductivity; scanner of electrical conductivity; soil properties

\section{Primjena načela elektrovodljivosti i uporaba EC skenera za utvrđivanje svojstava tla}

Izvorni znanstveni članak

Istraživanja (2011. i 2014.) su obavljena na pokušalištu tvrtke Belje i to o elektrovodljivosti tla i njenom značaju pri inventarizaciji tala uz izradu karte elektrovodljivosti.Ovim istraživanjem potvrdila se hipoteza o značaju primjene načela elektrovodljivosti pri utvrđivanju svojstava tla uporabom skenera EC. U pogledu primjene metoda prema načelu elektrovodljivosti tla, evidentno je da randomizirana metoda uzorkovanja odnosno uzorci nisu dovoljno homogeni i precizni, dok prediktivna metoda uzimanja uzoraka je naprednija a uzorci su homogeniji i bolje reprezentiraju stanje na proizvodnoj površini. Tijekom provedenih istraživanja metodom "Z sheme" obavljano je 324 GPS točki, dok je pri uporabi randomizirane metode izbrojano 252 GPS točki s time da primjenom ove metode nije potrebno prekriti cijelu površinu. Ova činjenica ukazuje na to da je pri izradi karte namjene u poljoprivrednoj praksi, ova metoda posebno pouzdana kao preporuka za odlučivanje u svezi agrotehničkih zahvata, primjerice u gnojidbi, zaštiti bilja, melioracijama, te niveliranju terena.

Ključne riječi: agrotehnika; biljna proizvodnja; elektrovodljivost; skener elektrovodljivosti; svojstva tla

\section{Introduction}

One of the most important areas in which precision agriculture is applied is management of variability of soil properties, which is extremely important for certain decision making [1].

Authors [2] have developed, through a computer model of assessment of benefits for crops, which is supported by GIS, a visualisation of agricultural area and the prediction of its production qualities, by which a detailed analysis, planning and division of agricultural production is possible. Accurate maps are needed for precise plants production. Graphical organisation of data concerning the soil is usually presented through land maps, that can be obtained in several ways, while geopositioning in real time with a help from the satellites. Authors [3] induce that the recommendation for fertilisation must have a physico-chemical data of soil analysis as a foundation, and that the calculation of the required dosage must take into account the profitability, realistic possible crops yield, the specific needs of the plant species and the potential soil fertility.

Authors [4] point out the higher quality, lower production cost and less impact on the environment as requirements that have to be fulfilled in developed countries by using precision machinery.

The success of the precision agriculture depends on efficient and reliable methods for collecting and processing of spatially conditioned data concerning the production area. Predictive, in other words digital, mapping of the soil is one of the most topical themes, while the application of precision agriculture requires highly defined spatial information about the soil. According to [5] mapping of the soil can be performed by both a method based on the knowledge and as a method based on data. The method of conventional (randomized) mapping of the soil based on data is characterised as being too qualitative. These two methods can be combined in a mixed approach. The goal of digital mapping of the soil is the spatial prediction of soil properties by combining spatial data and the data obtained by remote research.

Sampling can be done on the whole plot (accidentally or randomised, diagonally, Z-scheme, a net) or on a control (representative and exactly located) plot (benchmark causing) when recurring sampling, to determine the trend, is predicted [6].

Authors [7] have, using the protocol of electrical conductivity, specially characterised the changes in the physico-chemical properties of the soil. The protocols consisted of eight general steps: establishment of research of electrical conductivity of the soil, collecting data with the mobile GPS equipment, determining of exact places for soil sampling, sampling, laboratory analysis, calibration of readings and laboratory identified electrical conductivity, spatial statistical analysis and development of a GIS database and graphical presentation as well.

In paper [8] field measurements of soil conductivity are used for mapping of spatial variations of several edaphic properties: salinity of the soil, the clay content or depth of layers rich in clay, the content of water in the soil, the thickness of the sand deposited by flood and the 
amount of organic matter. Additionally, conductivity of the soil measured on the field is used for determining various anthropogenic properties, irrigation, draining and patterns of compaction caused by agricultural machinery.

Initially the conductivity of the soil was used in agriculture to measure the salinity of the soil. Its use has significantly improved and has become a widely accepted means for determining the spatial variability of several physical and chemical properties of the soil. The details of the conductivity of the soil are invaluable and enable the establishment of spatial data for assessing the soil quality.

Authors [9] have measured, using the electro conductivity, the amount of water in five types of soil and have confirmed the impact of changes in the amount of water for future mapping of the soil. The biggest differences in readings were in more humid soil. Therefore, in order to make the mapping of the soil as precise as possible, it is recommended to perform the measurements of conductivity when the soil is moist.

Authors [10] have, using a scanner, performed measurements on four agricultural areas, at two depths 0 , $3 \mathrm{~m}$ and $0,9 \mathrm{~m}$ in order to determine the connection between the conductivity of soil and crop yield. It was determined that there was no direct impact on the yield. Authors [11] have established that daily changes in temperature do not significantly affect the readings of electrical conductivity of the soil.

Authors [12] have conducted an unattended classification of topographic characteristics and electrical conductivity of the soil and have determined that the height and the electrical conductivity of the soil are the most important factors in the performance of unsupervised classification, while the slope is less important, but nevertheless should be taken into account.

Measurements with six discs (electrodes) were carried out by using a scanner. The correlation between the measured electrical conductivity of the soil and soil prudential value read from the existing maps was analysed. The results have shown that the correlation is present, and it is therefore concluded that measuring of the conductivity of the soil is proved to be a quick and inexpensive procedure for determining the variability of the soil, whereas prudential value with its reproductive capabilities can be used in precision agriculture as a technical support [13].

Ref. [14] mention that GIS technologies provide the right framework for the collection, analysis and interpretation of complex spatial and tabular data and that the mapping and spatial concept of time and space are very necessary for the use and the management of resources (Land Use Management).

This research should confirm the hypothesis about the importance of applying the principle of electro conductivity in determining the soil properties using EC scanner for electro conductivity and that the new method of sampling the soil ( $\mathrm{Z}$ scheme) is more effective and more precise regarding the quality of coverage rate of the area. After such analysis, all agricultural operations are simpler and more efficient (accurate use of fertilisers, pesticides and other resources in agriculture which are in connection with the ground).

\section{Materials and methods}

Researches have been performed (2011 and 2014) on the experimental fields of the Belje Company about electro conductivity of the soil and about its importance in the process of inventorying of the soils while making the electro-conductivity maps (eutric brown luvisol).

Electrical conductivity is the ability of the material to conduct electric current and is expressed in milliseimens per meter (MSM-1). The electrical conductivity of water is its ability to conduct electricity. Concerning electrical conductivity it is assumed that the water contains ions that can carry electrical potential- the current. The current is an indicator of ionization of water.

Prior to using maps as a basis for management, the necessary information about the spatial division of significant properties is needed. Pieces of information about distribution of nutrients and yields from plots are of primary importance. They substantially determine the economic and environmental success of breeding. Data collected prior to distribution of nutrients also have a great significance, and these are the results of chemical analysis, information about the structure and texture of the soil, electro conductivity and terrain levelling.

Electro conductivity of the soil is an indirect measure which correlates well with several physical and chemical properties of soil. Different types of particles in the ground have different conductivity, as for example clay has a high and sand a low electro conductivity. By using the electro conductivity it is possible to determine the texture and size of the soil particles. It is also possible to determine the differences in the content of soil organic matter and cation exchange capacity.

Water content in the soil, the percentage of clay and increase of organic matter, soil depth above the clay or stone layer, salinity and soil temperature can be measured by using the electro conductivity scanner [15].

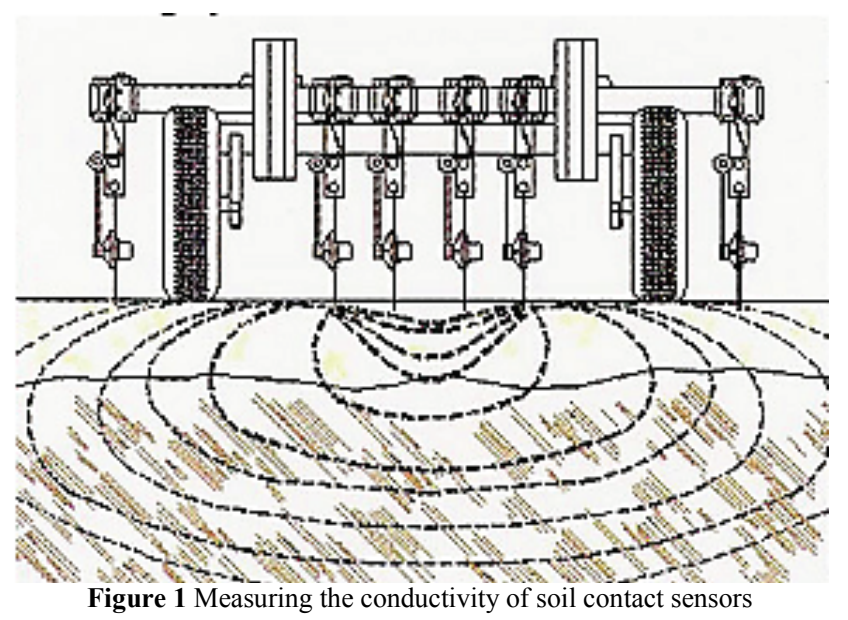

There are two types of sensors used for measuring the electro conductivity of the soil: contact and contactless sensors. Contact sensors (Fig. 1) come into contact with the ground to take readings of electro conductivity. Two or three pairs of coulters are usually used electrodes that enter the soil only a few inches deep into the ground. One pair conducts electricity into the ground, whereas the other ones measure the voltage drop between them and thereby the amount of electro conductivity is measured. 
The contact sensors measure electro conductivity at two depths; shallow (up to $30 \mathrm{~cm}$ ) and deep (up to $90 \mathrm{~cm}$ ). It is very important to periodically check if the coulters -the electrodes are isolated from the metal frame of the scanner and whether they are isolated from each other.

The current soil humidity is of great importance for obtaining good results of scanning, which should be at least about $10 \%$ above the wilting point. If the humidity is higher, the readings of electro conductivity will be also higher, but the relative values between different types of soil particles will remain constant. In case of rain during scanning, it is necessary to make separate records so that the data can be later equalised.

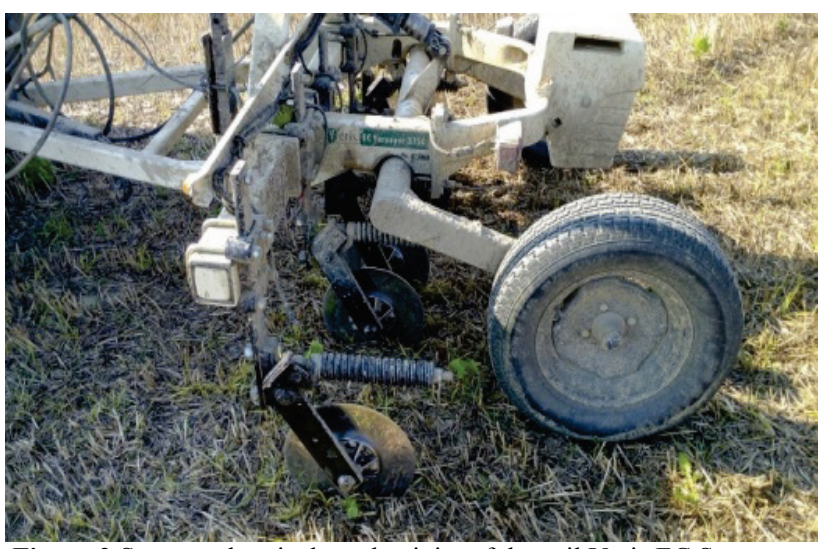

Figure 2 Scanner electrical conductivity of the soil Veris EC Surveyor 3150

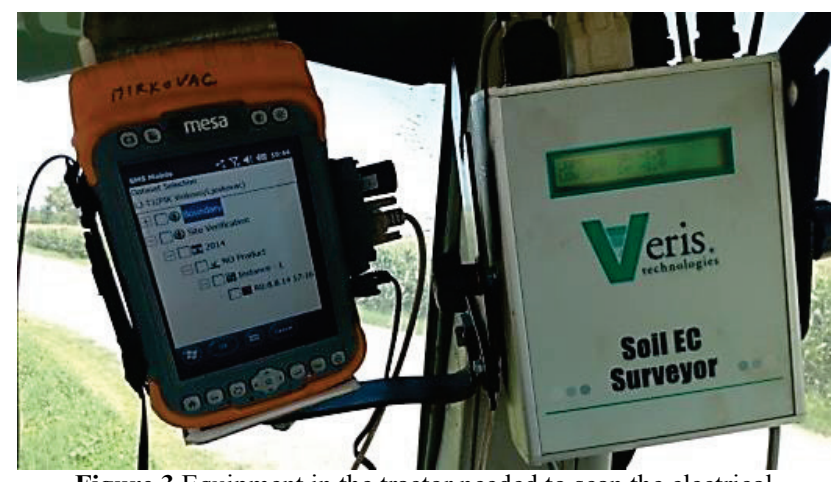

Figure 3 Equipment in the tractor needed to scan the electrical conductivity of the soil

Scanner for electro conductivity of the soil Veris EC Surveyor 3150 - was aggregated by a tractor type FENDT 411. It is important to check prior to use whether every disc rotates slowly with no sudden stops, to clean layers of the earth and to lubricate disc casing. Secondly, connect the box Veris Soil EC (Fig. 3), using a cable, to the scanner and pull out a black test box connected to the box Veris Soil EC. Thereafter begins the process of resistance measurement on each disc individually with the help of ohm meter. There are six slots on the black box, for each disc separately, the test device is set in the slot of the black box, and minus side relies on the disc depending on the sloth on the black box. The controller for measuring should show readings $0 \div 2$ ohms, in case of greater resistance, resistance is adjusted by screwing or unscrewing of each disc with the help of screws located in the middle of the disc casing. In case the controller even afterwards shows high values, disc casing needs to be dissembled in order to remove excess grease or dust that is located between the wall and casing of the disc. Insulation of the discs must also be checked.

The procedure for checking the insulation of discs is carried out by connecting one ohm meter cable to the disc and the other to the frame, and thereby check all discs and the resistance between the discs. If the discs are isolated the readings on the ohm meter will show zero. The speed of the scanner is $12 \div 20 \mathrm{~km} / \mathrm{h}$ and when turning the machine on the headland it is necessary to raise the scanner on wheels, so that there would not be any bending of the disc carrier or the disc itself. Working reach of the machine is $16 \div 24 \mathrm{~m}$.

Before work, conditions on the surface must be assessed, if it is not evenly processed, i.e. if it is partially processed or irrigated, every part of area is scanned separately, especially because of the difference in the values obtained when scanning. If the upper $7 \div 8$ centimetres are dry, the conductivity can be hindered and the readings will not be consistent. Working depth is from 3 to 7 centimetres.

When working with a scanner (Fig. 2) the tractor is fitted with a pocket PCAgLeader Mesa with its SMS Mobile software. It is used for identification of parcels and for collecting of data obtained from the scanner in real time. At the end, USB memory data is transmitted via USB memory to the SMS Advanced software for further processing. The map of conductivity of soil is entered in the SMS program and by using a randomized method and "Z scheme" mapping of sampling is started. Before interpolation it is necessary to review the unprocessed records in order to detect potential erratic readings caused by human activity.

Sampling of soil- the analysis of the soil is based on response of individual crops to fertilisation according to the amount of available nutrients in the soil, therefore a good soil analysis depends on a representative sample. The sampling must be based on field variations, topography of the plot and on the type of the soil [16]. Samples for crops are taken to the depth of $30 \mathrm{~cm}$, for permanent crops $0 \div 30$ and $30 \div 60 \mathrm{~cm}$ and in protected areas $0 \div 15 \mathrm{~cm} \mathrm{[17].}$

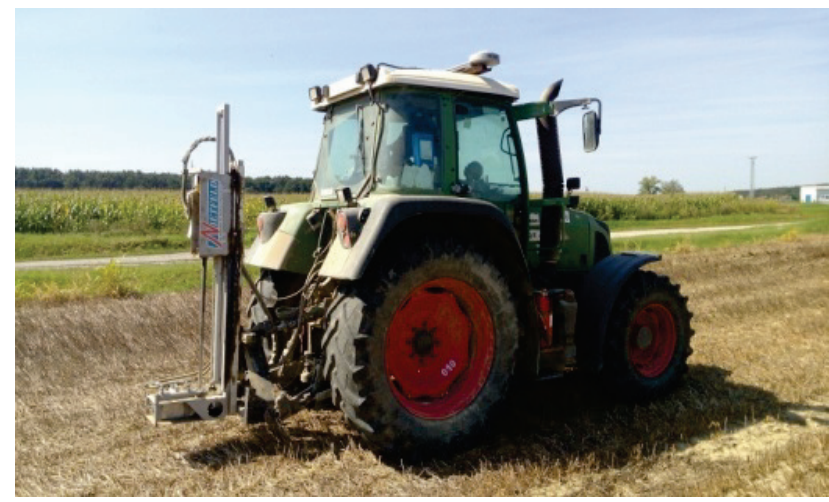

Figure 4 Sampling Soil probe NietfeldDuoprob to the tractor Fendt 4

When taking samples of the soil, a handbrake must be engaged in the tractor, otherwise the probe will not work. On the probe (Fig. 4) there are two small drawers for storing samples at work, and it is operated by a remote controller that has the ability to store samples in one or the other drawer. 
The tractor, on which connection of the probe is conducted, should have on hydraulics levers clips for stabilizing, due to high resistance of probe while drilling the ground. Otherwise, the probe will not fully perform its function. On the upper right side of the probe there is a measuring slot which shows the depth of penetration of the probe into the soil, and by using it the depth of sampling soil is determined. Each sample is marked with the name of the business entity, a label of agricultural area and a belonging unique number, in order to facilitate further manipulation in the laboratory and connect obtained laboratory results. The content of nutrients in the soil is determined in the samples, the lack or excess of nutrients is identified, the crop response to added nutrients is estimated and fertility is assessed.

\section{Results}

Created maps of electro conductivity of the soil (Fig. 5) show the texture and salinity of the soil and serve for better determining of sampling location. Mapping of electro conductivity of an agricultural area is done only once, except in cases of significant soil movement (flattening of depressions of a plot).

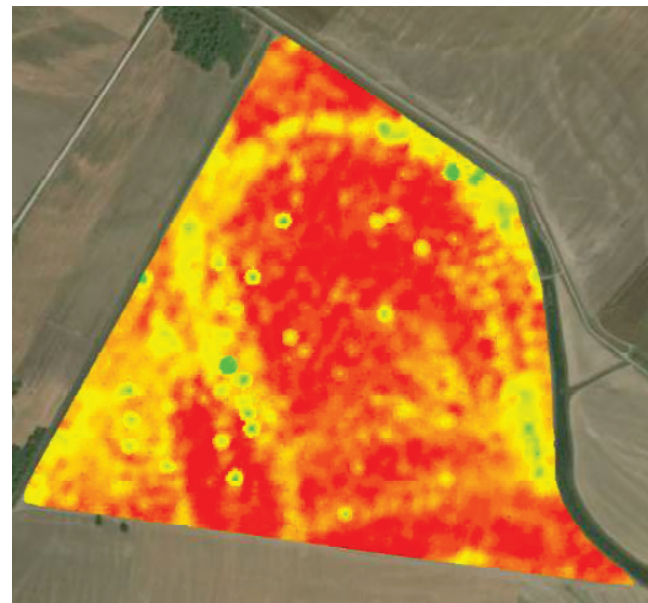

Figure 5 Map of the electrical conductivity of the soil on agricultura area $\mathrm{T} 05-20$

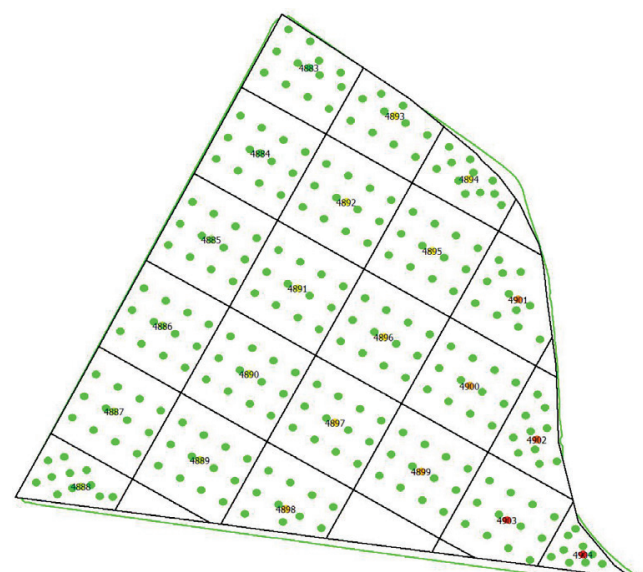

Figure 6 The sampling plan of agricultural land T05-20 randomized method

Maps of electro conductivity of the soil are displayed as polygons without interruptions, which are divided into classes and shown in different colours. By putting the values of conductivity into classes according to the principle of equal value, the number of classes is determined arbitrarily. The general pattern of soil texture is already visible within three classes and it does not change significantly by increasing numbers of classes.

Randomized sampling method is a conventional method. Its disadvantage is that most of the area is not square shaped (Fig. 6) and that the number of samples on the entire surface is not proper and equal. The samples are, compared to the corresponding polygon, not sufficiently homogeneous and precise. Average sample covers about 12 stitches of probe on an area of 5 hectares, or about $1 \mathrm{~kg}$ of native soil.

The predictive or digital sampling method is a more advanced method whereby the polygons of irregular shapes are drawn (Fig. 7), out of which sampling is performed. Its advantage is a better coverage of the whole agricultural area. As an example of predicative method and implementation of sampling (Fig. 7) a production area T05-02 was used. The determining and chart plotting of each sample was made on the basis of pre-made conductivity maps. The polygons with similar sol texture are irregular and of different sizes $(3 \div 7 \mathrm{ha})$, therefore the number of stitches for each sample varies.

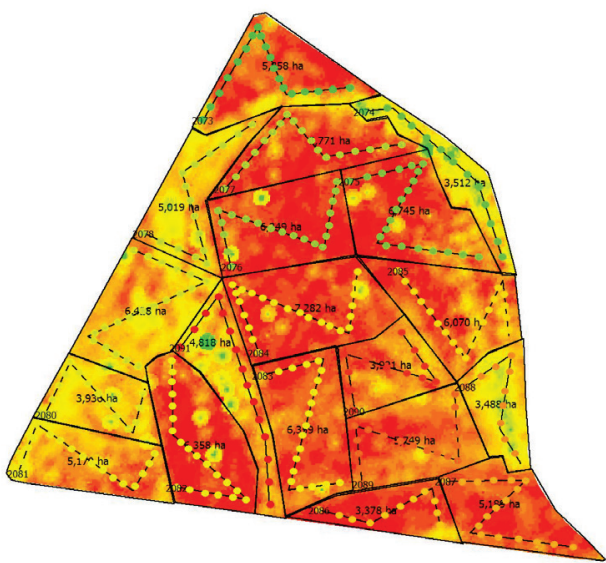

Figure 7 The sampling plan surface T $05-20$ to $\mathrm{Z}$ scheme based on the electrical conductivity of the soil

During the research with method "Z scheme" 324 GPS points were performed, while when using randomised method 252 GPS points were counted and as seen on the map number 6 , the whole area was not covered. Therefore the samples obtained through method "Z scheme" are more homogenous and show greater accuracy when preparing maps for fertilizer recommendations.

\section{Conclusion}

Based on a two year research on the importance of the implementation of the principle of electro conductivity and use of EC scanner in agriculture, i.e. in growing of crops, it can be asserted that the new method of soil sampling ( $\mathrm{Z}$ scheme) is more efficient and more precise concerning the better area coverage. Following such an analysis, all agricultural operations are simpler and more efficient (more accurate application of fertilisers, pesticides and other resources in agriculture connected to the ground). 
Concerning the application of method according to the principle of conductivity of the soil, it is evident that the randomized sampling method has the disadvantage that most production areas are square in shape and that number of samples over the entire surface is not proper and equal. The samples are, compared to the corresponding polygon, not sufficiently homogeneous and precise. On the other hand, the predictive method of sampling is advanced in which the polygons of irregular shapes are dawn, based on which more competent sampling is done. Its advantage is a better coverage of the whole agricultural area. Determination and chart plotting polygons of each sample is made on the basis of pre-made maps conductivity.

During the research with method "Z scheme" 324 GPS points were performed while when using a randomized method 252 GPS points were counted, even though it is not necessary to cover the whole surface, therefore samples with methods of " $\mathrm{Z}$ scheme" are more homogeneous and show greater accuracy in the preparation of maps intended for agricultural practices. They are especially reliable as recommendations for decision-making for agricultural operations, for instance in fertilizing, plant protection, land reclamation (drainage, irrigation), and levelling the ground.

\section{References}

[1] Jurišić, M.; Stanisavljević, A.; Plaščak, I. Application of geographic information system (GIS) in the selection of vineyard sites in Croatia. // Bulgarian Journal of Agricultural Science. 16, 2(2010), pp. 235-242.

[2] Vukadinović, V.; Bertić, B.; Đurđević, B.; Vukadinović, V.; Jug, I.; Kraljičak, Ž. Analysis of the benefits of land resources of eastern Croatian functional model. // Agriculture. 17, 1(2011), pp. 64-68.

[3] Jurišić, M.; Plaščak, I. Geoinformacijski sustavi GIS u poljoprivredi i zaštiti okoliša. University of Josip Juraj Strossmayer, Faculty of Agriculture, Osijek, 2009.

[4] Marković, D.; Pokrajac, S.; Simonović, V.; Marković, I. Economic evaluation of GPS technology in agriculture in Serbia. // School of Business. 3, 4(2013), pp. 1-11.

[5] Omran, El. E. On - the - Go Digital Soil Mapping for Precision Agriculture. // International Journal of Remote Sensing Applications. 2, 3(2012), pp. 20-38.

[6] Grubeša, D. Sampling methods of soil and plants, Finalthesis, University of Josip Juraj Strossmayer in Osijek, Faculty of Agriculture, Croatia, 2014.

[7] Corwin, D. L.; Lesch, S. M. Characterizing soil spatial variability with apparent soil electrical conductivity: I. Survey protocols. // Computers and Electronics in Agriculture. 46, (2005), pp. 103-133. DOI: 10.1016/j.compag.2004.11.002

[8] Corwin, D. L.; Lesch, S. M. Apparent soil electrical conductivity measurements in agriculture. // Computers and Electronics in Agriculture. 46, (2005), pp. 11-43. DOl: 10.1016/j.compag.2004.10.005

[9] Brevik, E. C.; Fenton, T. E.; Lazari, A. Soil electrical conductivity as a function of soil water contentand implications for soil mapping. // Precision Agriculture. 7, (2006), pp. 393-404. DOI: 10.1007/s11119-006-9021-x

[10] Ryšan, L.; Šarec, O. Research of correlation between electric soil conductivity and yield based on the use of GPS technology. // Reasearch in Agricultural Engineering. 54, 3(2008), pp. 136-147.
[11] Brevik, E. C.; Fenton, T. E.; Horton, R. Effect of Daily Soil Temperature Fluctuations on Soil Electrical Conductivity as Measured with the Geonics EM - 38. // Precision Agriculture. 5, (2004), pp. 145-152. DOI: 10.1023/B:PRAG.0000022359.79184.92

[12] Fraisse, C. W.; Sudduth, K. A.; Kitchen, N. R. Delineation of Site - Specific Management Zones by Unsupervised Classification of Topographic Attributes and Soil Electrical Conductivity. // American Society of Agricultural Engineer. 44, 1(2001), pp. 155-166. DOI: 10.13031/2013.2296

[13] Mimra, M.; Kroulik, M.; Altmann, V.; Kavka, M.; Prošek, $\mathrm{V}$. The analysis of the relationship between the electrical conductivity values and the valued soil - ecological units values. // Reasearch in Agricultural Engineering. 54, 3(2008), pp. 130-135.

[14] Jurišić, M.; Frangeš, S.; Plaščak, I.; Šiljeg, A. Methodology of Development of Purpose Maps in GIS Environment Resource Management. // Geodedski list. 90, 1(2013), pp. $1-12$.

[15] Virginia Cooperative Extension, Precision Farming Tools Soil Electrical Conductivity, Virginia State University, 2009, https://pubs.ext.vt.edu/442/442-508/442-508_pdf.pdf

[16] Vukadinović, V.; Matković, B.; Vukadinović, V.; Đurđević, B.; Semialjac, Z. Metodologija utvrđivanja pogodnosti za navodnjavanje krških polja. // Zbornik radova 44. Hrvatski i 4. Međunarodni simpozij agronoma / Opatija, 2009, pp. 3334.

[17] Federalni agromediteranski Zavod, Upute za uzimanje uzoraka tla za agrokemijska istraživanja. Mostar, 2011, http://www.faz.ba/galerija/agrokemijskaispitivanja/194/ima ges/dokumenti/194/Upute\%20za\%20uzimanje\%20uzoraka \%20-\%20Agrokemijski\%20laboratorij.pdf

\section{Authors' addresses}

Mladen Jurišić, PhD, Full Professor

Faculty of Agriculture,

Kralja P. Svačića 1d, 31000 Osijek, Croatia

E-mail: mjurisic@pfos.hr

Ivan Plaščak, PhD, Assistant Professor

Faculty of Agriculture,

Kralja P. Svačića 1d, 31000 Osijek, Croatia E-mail: iplascak@pfos.hr

Željko Barač, MSc, Assistant

Faculty of Agriculture,

Kralja P. Svačića 1d, 31000 Osijek, Croatia

E-mail: zbarac@pfos.hr

Domagoj Zimmer, MSc, Assistant

Faculty of Agriculture,

Kralja P. Svačića 1d, 31000 Osijek, Croatia

E-mail: dzimmer@pfos.hr 


\section{WORLD SUSTAINABLE BUILT ENVIRONIMENT Conference 2017 Hong Kong}
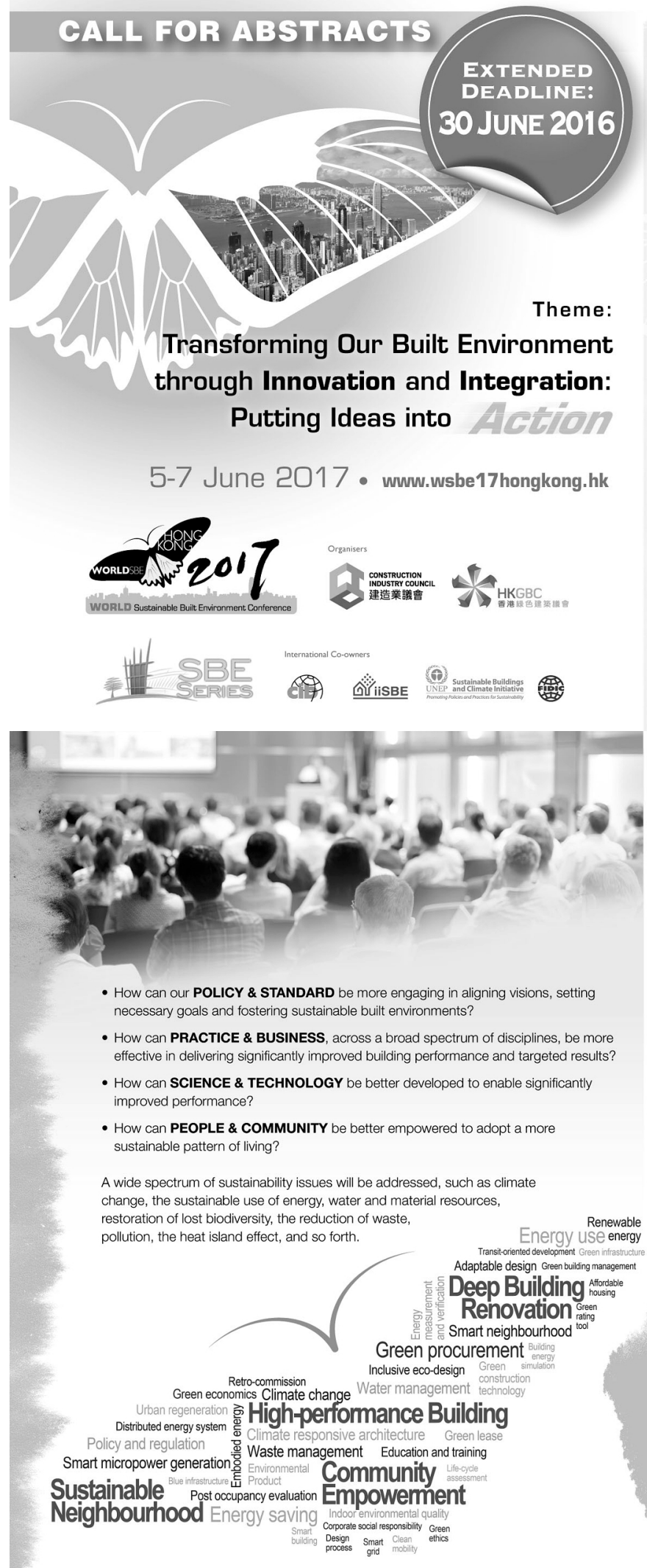

The Construction Industry Council prent the World Sustainable Built on 5-7 June 2017 in Hong Kong.
About WSBEI 7 Hong Kong WSBE17 Hong Kong will bring together 1,800 green building advocates, policy-makers, academics, and industry practitioners from all over the world, offering an inspirational opportunity for delegates to "Put Ideas into Action" to transform the world's built environmen

\section{Introduction} (CIC) and the Hong Kong Green Building Council (HKGBC) jointly present the World Sustainable Built Kong (WSBE17 Hong Kong) to be he

As one of the densest and most vibrant urban environments in the world, Hong Kong is the perfect setting for conference participants to experience and discuss both the challenges and solutions involved in creating a sustainable built environment. Serving as a strategic gateway to Mainland as a strateg Kong to Mrovides an unp Hong viewpoint for reviewing and discussing China's rapid urbanisation. WSBE17 Hong Kong is the world conference of the 2015-2017 cycle of the renowned SBE Conference Series, which is now considered to be the most influential of its kind globally. Following Hong Kong's selection as the host city, WSBE17 Hong Kong will conclude the cycle by ambracing all of the findings from the 20 regional conferences held in different parts of the world in 2016.

The conference will celebrate the continual efforts and achievements of different regions of the world in terms of sustainable built environments of various scales, with a particular emphasis on urban neighbourhoods and buildings.

Conference Focus

Presentations, exchanges and debates at WSBE17 Hong Kong will focus on innovative and integrative whole-system thinking and practices in sustainable built environment. The event comprises four major discussion areas:

1. Sustainable Neighbourhood

2. Deep Building Renovation

3. High-performance Building

4. Community Empowerment

The conference will examine how innovation and integration are able to synergise and interconnect different domains while also addressing a host of inter-related question

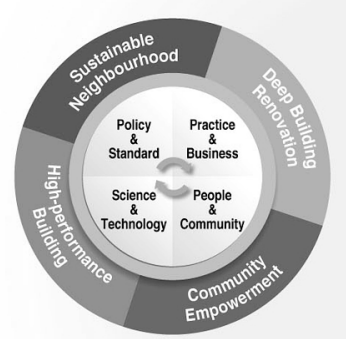

Key Dates

30 June 2016

5 August 2016

30 September 2016

15 November 2016

30 November 2016

\section{Deadline for abstract submission} Submission through the WSBE17 Hong Kong website www.wsbe17hongkong.hk

Notification of abstract acceptance Deadline for full paper submission Reviewers' feedback to authors

Final submission deadline

- All papers will be published in e-proceedings with an ISBN Selected papers may be considered for publication in the special issues of international journals partnered with WSBE17 Hong Kong including - Energy and Buildings - Indoor and Built Environment.

31 December 2016 uilding Research \& information

Notification of full paper acceptance

Past Editions of World SBE Conferences

- World Sustainable Building Conference 2014, Barcelona, 28-30 October 2014 - World Sustainable Building Conference 2011, Helsinki, 18-21 October 2011 - World Sustainable Building Conference 2008, Melbourne, 21-25 September 2008 - World Sustainable Building Conference 2005, Tokyo, 27-29 September 2005 - World Sustainable Building Conference 2002, Oslo, 23-25 September 2002 - World Sustainable Building Conference 2000, Maastricht, 22-25 October 2000

\section{Registration Fee}

Early Bird Rate at HKS4,800 for 3-day Conference \& Exhibition

(including Day 1 Networking Luncheon, Coffee Breaks and Conference Kit)

Registration will be open in September 2016.

Date and Venue

WSBE17 Hong Kong will be held on 5-7 June 2017 at the Hong Kong Convention and Exhibition Centre.

The three-day conference will comprise keynotes, roundtables and over 100 parallel sessions and specia forums, as well as a concurrent exhibition and green building tours, etc.

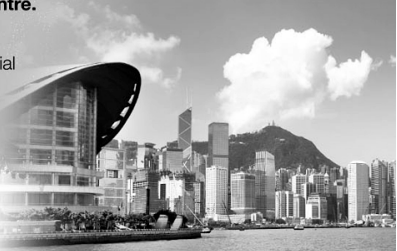

